\title{
An Unnoticed Analogy between the Timaeus and the Laws
}

\author{
Marwan Rashed
}

\begin{abstract}
The question of the relationship between the Timaeus and the so-called "unwritten doctrines" (agrapha dogmata) gave rise to many discussions since Antiquity until more recent times. The present paper focuses on what seems to constitute their central point, namely the intermediate position of the mathèmata. Aristotle expressly attributes this doctrine to Plato but we don't find it in the dialogues. The paper first recalls the interpretation of the Timaeus $55 \mathrm{c} 7-\mathrm{d} 6$ according to which this important passage alludes to the distinction between Forms, mathemata and sensible things. It then proposes a new interpretation of the Laws V, 739a1-e7 which shows that a close analogy between the Timaeus and the three "constitutions" (politeiai) mentioned in the Laws is conceivable. This new interpretation has an impact on the overall interpretation of the Laws.
\end{abstract}

Due to rights restrictions, this chapter (pp. 187-212) is not available as an individual file in electronic format. It is originally published as Rashed, Marwan. (2018). Une analogie méconnue entre le Timée et les Lois. Les Etudes philosophiques, Vol. 181, copyright (C) Humensis (www.humensis.com). 